\title{
Indigenous Administration and Dispute Resolution System of the "Abo Gereb" and Its Essence of Democracy from the Modern Philosophical Perception
}

\author{
Bisrat Tesfay \\ Department of Civics \& Ethical Education, Wolaita Sodo University, Wolaita Sodo, Ethiopia \\ Email address: \\ btdesalegn@gmail.com \\ To cite this article: \\ Bisrat Tesfay. Indigenous Administration and Dispute Resolution System of the "Abo Gereb" and Its Essence of Democracy from the \\ Modern Philosophical Perception. Journal of Political Science and International Relations. Vol. 3, No. 2, 2020, pp. 36-43. \\ doi: $10.11648 /$ j.jpsir.20200302.12
}

Received: May 28, 2020; Accepted: June 15, 2020; Published: July 4, 2020

\begin{abstract}
This paper was targeted to emphasize and promote the traditional political and social perspectives of the abogereb. Abo-gereb is an indigenous administrative system and conflict resolution mechanism in Enderta, Wejereat Raya and the low land (Afar). The paper aimed to discuss the central activities and core problems of the abo-gereb, the role of the paper was to scrutinize the role of the traditional democratic system of, "Abo-gereb" to the current politics of Tigray and Ethiopia and attempts to identify the factors that weakens the indigenous traditional democratic system of the Enderta province "Abo-gereb" and put direction about its revival. In the end, the paper emphasizes the entity of the traditional administration of Abo-gereb and its articulation with the modern political thought of Hobbes and Locke. This paper also investigates the political failure of the administrative system of the Abo gereb; the peasants or Abo gerebs didn't have scientific program that enable them successful in defeating the colonial and imperial government. Finally, it exemplifies the political system of abo-gereb deserve the entity of traditional democracy and the role of this traditional administrative system to the contemporary democracy of the politics of Tigray, and Ethiopia and it explores several mechanisms to salvage the system of Abo gereb.
\end{abstract}

Keywords: Enderta Province, Abo-gereb, Indigenous, Democracy, Conflict Resolution, Administration

\section{Introduction}

Historically Enderta was a province covered a wide area for a long period of time. Enderta or Inderta is a former historical province of Ethiopia; it is located in the eastern edge of the Tigray highlands. Enderta is bordered on the west by Tembien, on the south and south west by Lasta and Wag, on the east by denkel (southern Red Sea region of Eritrea), and on the north by Agame and Adwa [1]. The word Enderta is a Ge'ez word, it mean that the "home of justice". The capital of Enderta province was Hintalo, admirably calculated by its position for the protection of the southern provinces against the enemy, on which it has been selected for his residence by the Ras [2]. Enderta was one of the strong provinces in the regime.

However, recently the Enderta province dissolved in to one district called Enderta woreda, which is located surrounding Mekele (capital of the region Tigray), south eastern zone in
Tigray; it is bordered on the west wukro, south west Samre, south Adigudom, and on the east Afar region.

Accordingly, in this paper I used Enderta as the old province which includes around ten districts, (Enderta Mekele, Dedeba Dergajen - Kwiha, Gabat melash - Hentalo, Wenberta - Maimekden, Bora-Selewa - Dala, Saharti - Gijet, GereAlta - TsigeReda, Waereb - Samre, Wajerat - Debub, Denkel, Zone two of Afar - Shekhet), [1].

Historically, the province of Enderta had been ruled by its own hereditary governors, at least, since the restoration of the Solomonic dynasty in 1270 [1].

Enderta Province is identified with the traditional administrative system which struggles against the colonial empire of the monarchical system in Ethiopia for a long period of time. Peasants were suffering more by the monarchical system of the empire in Ethiopia. The people of Enderta province (Enderta and Wejerat) has been tried to defend the challenging leadership of the monarchy by using 
different mechanisms. One and genuine mechanism that they were used to defend themselves from the harassment and exploitation of the colonial empire of the Ethiopian government was promoting and actualizing democratic administrative system on the district, province and the region, the so called abo-gereb.

\section{The Etymological Meaning and Administrative System of the "Abo-gereb"}

Literally, abo-gereb is Tigrigna word; it is one of the languages spoken in Northern part of Ethiopia, (Tigray and Eritrea). The word abo-gereb comes from the two Tigrigna words, abo and gereb. Abo- means "father", and gereb is "river". Therefore, abo-gereb is etymologically defined as the father/chief/leader of the river.

The peoples of Tigray were subjugated by the imperial state government for a long time. For the reason that, the peoples of southern and south eastern Tigray particularly, Raya Azebo, Wejerat and the Enderta community launch strong struggle against the state government. "The Raya and Wejerat, had a long history of militantly opposing state efforts to impose local administrators and the risti system of land tenure" [3]. As the result, "the Raya and Wejerat who for many years managed to retain much of their traditional culture and avoid state incorporation" [3]. Later, the peasants struggle extends to the other districts in the Enderta province.

The ultimate cause for those people to stand against the imperial government was the centralized power of the state. "The state did impose a chika shum (local administrator) over them and this served as one of the precipitating causes for their conflict with the central government" [3]. However, they were not welcomed with the local administrators selected by the state, without the consent of the people because the chika shum were exploiting the society. Then after they opposed the local administrators from the state and launched a war against them in 1942/43.

The indispensable aim of peasants struggle was to realize self-administration and determination. The native people's interest was to be governed by the local administrators who were elected by themselves on their consent. Moreover, people were officially believed that even the rivers on their province shall be administered by their local administrative system elected by themselves, not by the consent of the central government. And, to actualize their goal they establish an organization called Abo gereb to struggle the imperial regime.

However, the government officials of the regime called the peasants rebels against the government (Abo gereb) Shifta. The word shifta denotes relative connotation; "it were not homogeneous: some were basically criminals engaged in looting both peasants and nobles alike, but others were peasants deeply angered at their conditions and 'their discontent was in essence the peasants' discontent"' [3]. But, most of the peasant's rebellion (Weyane) was belong to the latter and an aggrieved local official turned shifta, Blatta Haile Mariam Redda, became its principal leader [3]. This peasant rebellion is known by the name, Qadamay (first) Weyane and this peasant rebellion was not Tigray wide.

The aggrieved parties united, temporarily, around a sense of 'provincialism'. Yet the notion of provincialism cannot be stretched too far [...] Only Enderta, Kilte Awlaalo, Tembien, and Maichew were fully involved. The local chiefs of Agame, Aksum, and Shire remained on the fence until the outcome of the conflict was known [4].

This quotation explained that, the rebellion against the centralized government of the imperial regime was held by peasants of Enderta, Wejerat, Raya, Samre, Selawa Tembien, Kielte Awlaalo. The Qedamay Woyane Rebellion of 1942/43 broke out due to high taxation, maladministration, corruption, and political feud [5]. Therefore, Abo gereb is normally defined as the peasant organization and agreement which was held among the districts under Enderta province. The peasants which were participated on the agreement representing their districts were, Wejjerat, Hint'alo, Inderta, Darga Ajen, Haramat, Abergelle, Samre, Serewa, and Gercalta met at a place called May-Derhu, Hint'alo [6]. Hintalo was the capital of Enderta province [2].

The primary agenda of the agreement was contented with two core campaigns; one is to stand together to struggle against the exploitation and harassment of the imperial regime, and to ensure self-administration by electing a leader from the local community on their consent [2]. "These are elected peasants of Abo gereb such as Blatta Hayle Maryam from Inderta, Bashay Gugsa from Hint'alo, and, Belay Woldya and Fitawrari Ya'ebiyo Wolday from Kilitte Awlaclo to lead the uprising under the general assembly", [6].

The local administrative system of Abo-gereb is an indigenous democratic political, social and environmental system originated on the Enderta province during the first weyane rebellion.

The members of the abo-gereb have different members, leader or administrative of the gereb, deputy administrative and ordinary members and they all have different political and social functions. The leader of all Abo-gereb in the Enderta province was Blata Hailemariam Reda from Enderta [6].

Clearly speaking, the people of Enderta province have been exercising very essential principles of traditional democracy and electing leaders for self-administration. The leaders of the districts in the province were directly elected by the society and serve their community in politics and social aspects.

The society of in the province was ruled by the abo-gereb, and abo-gereb is a local administrator directly elected by the wish of the farmers without any external enforcement. The members of the Abo gereb are elected from each kebeles (distict) in Enderta province and Wejerat. The function of Abo-gereb is administrators of political, environmental, and economical segments and these are included in these two genuine functions: administration, and conflict resolution. Districts in both areas are politically and socially 
administered by abo-gereb. The Abo gereb is active in negotiating when clash are occurred between/interpersonal and among groups too; for the reason that Abo gereb is deserved indigenous dispute resolution mechanism.

These seventy elders were also bestowed provincial authority by the governor of the province to legally represent Enderta and its people in a provincial level with neighboring districts, counties and provinces [6].

So far I argue that the traditional politics of Enderta province has an essence of traditional democratic system, for the reason that, members of the abo-gereb are elected from the society for the society. And, people are agreed to respect the regulation and accept the political and social judgments of the abo-gereb. As I have explained earlier, the numbers of the elders or leaders are seventy in number. These all members of abo-gereb are elected from all local districts and the members themselves elect other special members out of the seventy members that could control all political and social activities. Herewith, the administrative politics of the Enderta province has been exercising self-administration and self-representation within the district and the province wide. This is an essential feature of the traditional democracy.

Enderta province's people have been struggling against the anarchist government of Haileselassie and control the capital (Mekele), though it was defeated by the government after inhumanly bombarding the peasants of Enderta, Wejerat and Raya by the support of British force.

After a series of battles beginning 22 May 1943 that left the Woyene rebels in control of the provincial capital Mekelle and most of eastern Tigray, they focused their efforts on the government stronghold of Amba Alage. However, after three weeks of increasingly bitter attacks, the army, with the assistance of British officers and aerial bombardment, was victorious in October [3].

Later, the government was committed inhuman and vengeful acts over the peoples of Raya and Wejerat. According to Young.

Government retribution was quick and severe. The Territorials spread violence throughout Tigray, fines was levied, homesteads destroyed, and cattle confiscated. Of more long-term significance, the Raya and Azebo, who had been in the forefront of the rebellion, had their land taken away and were made tenants on it. Tigray's boundaries were also redrawn and the area they inhabited was assigned to Wollo.

This quotation explained that, beyond the destruction of farmlands, cattle, and homesteads over the people of Raya and Wejerat, the most unforgivable story was recorded by the central government of the Haileselassie regime. Currently, Raya is one of the most complained area by some elites and politicians of Amhara that was allocated to Wollo by the imperial government after the war of First Woyane. The elites and politicians of the Amhara region believe that "Raya was redrawn before the twenty seven years by the administration system of Eprdf." In fact Raya was a historical province of Tigray and even one district of Tigray that is Raya Kobo, which is now under the administration of the Amhara regional government, but it, is a historical territory of the province of Tigray. "A measure of provincial autonomy was thus retained, but the trend toward state centralization continued" [3].

Accordingly, the local administration system of the Abo gereb is a traditional democratic system of Enderta province's community.

This is a form of old age democratic process through which elected and assigned elders are representing their constituency in social, political, and governmental affairs within the empire of Ethiopia. In a communal or individual level, individual Endertans enjoyed self-representation within the district, county and even the provincial level; in Enderta, jural independence included the right to claim farmland and to represent oneself in community councils and in court [3].

The role of Abo-gereb is not limited to political administration and traditional negotiation when conflict (dispute) rose, but also it has a significant role in managing environmental resources, like, water and forests. Not only managing the resources but also fairly distributes to the community. For instance, the Abo-gereb fairly distributes water to all society based on the placed time schedule for irrigations and other agricultural activities. In the province most of the time disputes were associated with the using of land resources, and other environmental resources. Accordingly, in order to manage and control disputes among the society the Abo-gereb has a responsibility to administers and manages the natural and environmental resources wisely for the benefit of all society.

As we can see on the above paragraph, the function and aim of Abo-gereb is also to manage and resolve disputes among the society. Thus, Abo gereb deserves indigenous conflict resolution mechanisms in the province particularly Enderta, Wejerat and Raya, and this kind of resolution of conflicts on the province is known as, Irki Enderta.

\section{Conflict Resolution: Irki Enderta by the Abo-gereb}

What is conflict?

There is no single definition for the term conflict [7] but most of the time can be defined as a social, political and economic clash among the communal groups. Conflicts is inevitably happened among communal groups, logically it is happened because of people are not properly using their capacity of reason. Conflict is the clash between or among two/more peoples caused by the diversity of opposite interest. As long as people live together conflict is multifarious interaction among the communal groups. With this regard conflict is the result of clash of interests among the society in the country. Most of the time when the conflict is interpersonal it is caused by absence of use of our capacity to act in accordance with reason.

Moreover, peoples dispute in Enderta province are caused by the clash of interest to expand power and territory, to capture the fertile soil and green environment just to use 
natural resources as they want excessively. In short, the conflict may be caused by the wish of individuals and people to actualize their entire wish of using and consuming water, grass, and land excessively.

Physical conflict between two powers is harmful to anybody, and any group of people, because its consequence is bad. The main consequences of ethnic conflict are passing the life of people, and destruction of material resources and migration (displacement) of citizens.

However, we shouldn't be surprise on the occurrence of conflict, but the point is how to manage and resolve it with simple cost is what it has to be considered. There are two approaches of conflict resolution; the first one is legal; whereas, the other one is traditional or indigenous. But I only concerned with traditional dispute resolution mechanism. The communities in Enderta province have been exercising a traditional conflict resolution mechanism; this kind of mechanism is known as, Irki Enderta (Enderta's negotiation). Irki Enderta dispute resolution mechanism use elders as mediators who are chosen by and recognized to the parties and/or communities to resolve and re-establish the peace of the society. These elders who resolve disputes in Enderta province, called Abo-gereb.

The indigenous conflict resolution mechanism is helpful for controlling and resolving conflicts in Africa in general and Ethiopia in particular [8]. There are diverse conflict resolution mechanisms which have been exercised in Ethiopia [9]. Traditional dispute resolution mechanisms are good in normalizing interpersonal relationships among the societies. It has a substantial role for the re-establishment of social relationship and peaceful life than the legal one; fore the reason that the legal one is more open to vengeance by considering the historical culture of Ethiopia.

In almost all of the Ethiopian societies, vengeance is a culturally accepted instrument for redressing injury, and the men of the victim's side are duty bound to take vengeance against the killer or one of the killer's close relatives [10].

Abo-gereb is one of the conflict management and resolution apparatus exercised in Enderta, Wejerat and some part of the boarder of Afar region. The members of councils are elected by considering the following qualities; who are most esteemed, wise, treat all fairly and native elder men. The council of elders among the Enderta community was referred to as the "Abo-gereb" and used to act as an arbitral in dispute resolution. A decision given by the council members was respected by the community; no one can deny it. Unfortunately, if someone committed a mistake or crime (killed a person) and when he/she escape from the province to other place, his family and neighborhood will be punished representing him. For this reason, the probability of criminals to escape from the council elders and hide themselves from the community is too low.

When conflicts are raised in Enderta and wejerat, the abogereb gives a decision over the criminal and punishes him, the penalty maybe in cash or in kind (cattle). Thus, the traditional dispute resolution of Irki Enderta plays a significant role in maintaining peace and stability in the community. Thus, appealing to the traditional system of conflict management is ideal to live in peace. The people have been relied on traditional activities and the guidance of old people, and this resulted from religious morality.

The elders insist and pressurize them to come to the process, and mostly do not leave without getting their consent to come to the peaceful settlement [11]. Finally, the council elders conclude their meditation by inviting them for greeting and then making peace between them.

However, even though the traditional dispute resolution of the elders of Irki Enderta plays a substantial role in reestablishing and maintaining peace on the society, there are critical challenges that weaken the mechanism. The core challenge that weakens the Irki Enderta was absence of encouragement and motivation from the government. There were no significant support and recognition by the government to the Abo-gereb (elders).

\section{The Philosophical Perspectives of the Abo-gereb}

\subsection{Hobbes's Social Contract}

According to Hobbes, the state of nature is a state of war; as he puts it in the Elements, 'the estate of men in this natural liberty is the estate of war' [12]. For him people in the state of nature are in state of war (i.e. every one stands to kill everyone), because, there is no government in the state of nature [12]. "It is the war of all against all." According to Hobbes, people in state of nature are always in war to secure their private property. Thus, private property and self-interest is core cause of the war in Hobbes's state of nature.

Accordingly, Hobbes recommended social contract to end the state of war of all against all and stabilize the political, social and economic quarrels. The social contract is held among the society and they elect a king or leader. The king controls every activities of the subject, for instance, if somebody kills another the king gives a decision and punish him upon his crime.

The people of Tigray were exploited by the imperial and colonial government for a long time and they have been struggling against the government to free themselves from the exploitation. Likewise, the Enderta, Wejerat and Raya society was inhumanly crashed by the imperial government of Haileselassie. In 1943-1944, with British air support, Addis Ababa violently suppressed the Woyane insurrection, a serious peasant uprising in Tigray [13]. Haileselassie also bogged down to stop the spread of the first woyane movement with the help of the British colonial government.

The administrative system of the Abo-gereb has been used different struggling apparatuses and structures. The local representatives of all gereb of Enderta meet at Hintalo, specific place of May Derhu and they get treaty to reject the nasty administration of the imperial government and struggle against the government to liberate their society from the exploiting government. Their social agreement/treaty was known by, "wu'elna wu'el may derhu yekhun", this is 
Tigrigna language; it can be translated as "Our movement should always be Mayderhu's treaty".

The aim of the peasants from the May Derhu agreement was:

Controlling Tigray within short period of time, they talk over how could they struggle and win on the war with the state government and they made rule of law which is called law of gereb and later they deserve it law of Tigray; it was supreme law, and they elect the leader of the Abo-gereb, Blata Hailemariam was directly elected by the abo gereb as the leader.

The law of Abo gereb contained essential points such as:

1. Everyone should neglect the law of the emperor and his followers and respect the new replaced the law of gereb.

2. Individuals should have appeal to the abo gereb, not to the local administrators of the state to get justice when they face problems. This principle involves bringing honey, goats, and butter to the local administrators of the state is strictly prohibited. If anyone broken this principle, he/she will be punished by the law of gereb.

3. Exploiting and harassing by the stronger to the weaker, rich to the poor is strictly prohibited.

4. Vengeance is forbidden.

5. Abstaining from cooperating and supporting the objective of abo gereb is outlawed. If anyone refrain himself from supporting the objective of the abo gereb he/she would be alienated be from the society, and no one would participate in his funeral when the person died.

6. When any unintended war has occurred, every member of the community should get out of home and take action against the enemy. Unless, the Abo gereb let the man wear ladies clothe, like dress and move in front of the mass on the street and market.

These all principles of gereb were comprehensively accepted by the people, due to under estimating the previous activities of Abo gereb in combating theft, hang and rape; it has been seriously punished those who are infected by these immoral acts.

Generally, the agreement contended: "they should never give up for imperial government to be exploited", every representative of each kebele (gereb) should be day and night watchman, they have to share each other all new and strange information, they decided on the treaty a specific period have time to meet and deal about the political movement of the province and others.

Thus, I would say the indigenous administration by the abo-gereb has been exercising the social contract. The modern view of Hobbes's and Locke's social contract was not strange to the society of Enderta, Wejerat, Raya, Samre, Tembien, Kielte Awla'alo and S. the social contract is made among the elected Abo gereb represents all districts or gereb.

For instance, Abo-gereb and the enderta society have exercised social contract in three ways:

One is to nominate their representatives from each gereb by the society directly and all abo gereb elect one leader, and respect all decisions given by them in political, environmental and social aspects.

The other one is to struggle against the exploitation of property and values of the people by the Ethiopian colonial empire of Haileselassie.

The last one is their strong stand and agreement for, "saying no for exploitation, and revolution against the imperial and colonial government".

Accordingly, the Abo-gereb has philosophical similarity with the modern political philosophy of Thomas Hobbes's view of social contract.

Even though the abo-gereb administrative organization was emerged in enderta province, but the whole part of Tigray was exploited by the colonial empire of Ethiopia. Peoples in Enderta province, Tigray could not own their property and led by their representatives during the colonial empire of Ethiopia (Emperor H/selassie).

Locke argued that, Property is normally thought of as a bundle of rights, and different treatments of property will include different items in the bundle. However, the Enderta society and other parts of Tigray were led by local administrators who were selected by the king (Emperor $\mathrm{H} /$ selassie) and they only get one third of their wealth and production. This was the core cause of the emergence of the abo-gereb in Enderta. However, private property is one of the most essential rights; it is one of the natural rights.

Later, the people get social contract among themselves and elect 70 (seventy) representative from each and every district (gereb) and these representatives directly lead the people. Even if the end of social contract of Hobbes's and Abo-gereb is different, making social agreement in itself is what makes both Hobbes and Abo-gereb analogous and similar. Hence, the political, economic and social consensus among the people is what it makes it similar with Hobbes's theory of social contract. And, the society keeps their promise by respecting the decision of the abo-gereb in every aspect.

However, when an individual from the Enderta society have broken the agreement or committed a mistake which is wrong according to the society, the abo-gereb is going to punish him in accordance with the agreement. Then, the criminal person has an obligation to accept the punishment willfully. According to Hobbes, breaking an agreement is for Hobbes a prime example of injustice or 'injury'. This respect of agreement (social contract) is the other point that has analogy with the idea of social contract.

For the reason that we can understand that how Abo-gereb was democratic and self-representatives elected by the will of the society. Accordingly, the traditional philosophical politics of (democracy) of Abo-gereb has a substantial similarity with the modern views of politic (democracy).

Contemporarily, democracy defined as the form of government based upon self-rule of the people and in modern times upon freely elected representative institutions and an executive responsible to the people, and a way of life based upon the fundamental assumption of the equality of all individuals and of their equal right to life, liberty (including liberty of thought and expression) and the pursuit of happiness [14]. 
Therefore, I would say the traditional democratic administrative Enderta more or less have significant role to the current spark light of democratic politics of Tigray.

\subsection{Locke's Social Contract}

Locke is a prominent modern political philosopher from Great Britain. His argument of state of nature has decisive role on the development of modern political philosophy. According to Locke, the social contract is held between subjects and the government. The subjects have obligations on what they have to and not to do, and the government have also responsibility on doing what it has to do and; refrain what it should not have to do. However, when the subject has broken the law, it will be punished by the government upon the law of the state. Moreover, when the government crossed the red line or broken the law of the state, Locke advice a revolution by the subjects against the government.

Locke said, if the government acts beyond its powers (as judged by the people), then this government is held to be 'dissolved' [14]. In this regard, Locke said, if the government is dictates the society and exploit their resource unwillingly, the society should rebel against the government and it should dissolve.

Likewise of Locke's argument, Abo-gereb administrative system was revolutionary, no tolerance to the exploitation by any imperial and colonial force. Abo-gereb is ultimately aimed to rebellion against the imperial and colonial government of Ethiopia. During that time the government of Ethiopia was harsh and nasty, the fundamental human rights (the right to property, to speech) were neglected.

To let down the system of the undemocratic imperial government, the societies of Enderta establish a new struggle organization, Abo-gereb. With this regard the Enderta society were actualizing their capacity of reason. Their reason was that they need freedom and they did not accept/allow all exploitations by the imperial government of Ethiopia. To actualize their freedom and stop the exploitation they have been used different struggle mechanisms. One of the mechanisms they used was revolution. They said no for any external imperials and internal colonization of the Ethiopian government and struggle for decades until they get freedom. This is the other example that they were exercising reason against exploitation.

Thus, the traditional democracy of Abo-gereb is analogous with political philosophy of John Locke.

Accordingly, this revolution against undemocratic and illegitimate government is an entity of the modern democracy system and modern political agenda. For this reason, the Enderta Abo-gereb was doing and exercising democracy during that period.

\section{The Political and Social Limitations of the Abo-gereb}

This topic contains the limitation of Abo-gereb with regards to the political administration system and social activities.

Part I: The first part is about the limitations of the conflict management and resolution of Abo-gereb (Erki Enderta).

There are some limits of indigenous abo-gereb's conflict resolution; these are bias, prejudice, and government intervention. Traditional or indigenous conflict resolution should be free, fair and independent of any governmental interventions. If government is officially intervened in the traditional resolution the conflict might be aggravated. And, the elders of societies should give neutral and make a correct decision. The other problem of the traditional conflict resolution it's excluding young and women from making decision just for the sake of fair decision. In the history not only Enderta, on the country wide women are excluded from negotiation; with this regar, in most customary dispute resolution mechanisms of Ethiopia, women are not treated equally [15]. This exclusion may aggravate the conflict into the harshest social and cultural problems, because the decision Abo-gereb may be counter to the interest of women.

Thus, I would say women the customary dispute resolution should be universal, all must be involved to make the arbitration more successful.

Part II. The limitations of the traditional Administrative System of Abo-gereb.

There are some essential problems with the traditional democracy of Abo-gereb. As I have tried earlier the members of Abo-gereb or self-representatives are elected by the people by considering some important requirements. But, women are excluded from the local elections for the member of Abogereb. Even the name "abo" is necessarily belongs to father (not mother). Thus, I would say, this exclusion of women (females) from the political administrative and negotiation/arbitration (abo-gereb) is erroneous from the point of view of equality.

The other limitation I found with this traditional democracy is concerned the financial benefits of the Abogereb. The members of the abo-gerb are not paid for their effort of administering and arbitrating when dispute occurred. They don't have any compensation for themselves. Thus, this absence of financial support may led them work inappropriate, and biased judgment and punishment.

The other limitation is goes to the time period of the Abogereb is unlimited. Accordingly, the political administrators of Enderta Abo-gereb should be elected and work for a specific period of time, because, periodic leadership (election) is one of the essential principles of modern democracy.

\section{The Role of Abo-gereb to the Contemporary Politics of Tigray}

Modern democracy came into existence by defining itself over against its predecessors and competitors as a revolutionary departure. Its champions often claimed that in criticizing traditional mores and institutional arrangements they had broken completely with a feudal and ecclesiastical past [16].

Likewise, the history of the traditional democracy of Abo- 
gereb of Enderta has an extensive role to the contemporary politics of Tigray and Ethiopia. The first pragmatic and democratic rebellion against the colonial empire of Ethiopian government was launched by the Abo-gereb of Enderta. The central role of the Abo-gereb was to struggle against the exploitation of the imperial government in Enderta and Tigray. By defeating and rejecting the legacy of the colonial empire they establish their own administrative system, Abogereb. The objective of the abo-gereb was to assure selfadministration and to be ruled by own representatives.

Therefore, the traditional democracy system of Enderta (Abo-gereb) has a vital role to the current spark light of democracy of Tigray and Ethiopia. Ethiopia is now follows an ethnic federalism, the power is hold on the federal and regional (local) government, unlike the previous colonial power of Ethiopia. But, this perspective was not strange to the society of the Enderta province. The Abo-gereb is elected by the people from each kebele (gereb) by analyzing the social and political quality and reliability of the elders. The Enderta society was administered by their representatives who elected themselves. This is a bit a central entity of democratic federalism.

Accordingly, as a researcher, I would say Abo-gereb has a significant role to the contemporary politics of Ethiopia, from imperialism, dictatorship (Derg) to democracy.

The other role of Abo-gereb to the contemporary politics of Ethiopia is conflict resolutions. Ethiopia is one of the most diversified countries in Africa. There are diversity of interests and heterogeneity of culture, language, color, religion and others. Following these conflicts has been occurring in most parts of the country. When conflicts are happened the society and government have used different formal and informal (indigenous) conflict resolutions.

Abo-gereb is also exercised within and out Tigray region. For instance, in 2017 different official groups has come from all parts of the country to Tigray (Enderta) to take experience on how to resolve conflict using the indigenous conflict resolution mechanism of the Abo-gereb.

Conflicts are happened on the boarder of Tigray and Afar caused by the clash of interest on the use of grass and water for their cattle. I am not surprised with the conflict, it is normal, but how to manage and resolve it is the point. Conflicts occurred between the two regions have been managed and resolved by the Abo-gereb via their representatives on abo-gereb of both sides. Thus, the Abogereb has a successful outcome in having smooth relationship between the two regions. In this regard, I would say abogereb has an important role in resolving conflicts, and stabilizing and democratizing the region and its neighbors.

Generally, the indigenous administrative system of abogereb could play a vital role to the development of the political philosophy of Africa.

\section{Conclusion and Recommendation}

\subsection{Conclusion}

Abo-gereb is a traditional democracy of the Enderta,
Wejerat and Raya, in which it administers the society by the Abo gereb (self) representatives. By that time even thinking about private property and power distribution is impossible, because the government was imperial and power is centralized. The Tigrean peasants could not own their property, they obtain only one third of their wealth/product. They were highly exploited by the imperial monarchical government. Following this, the peasants were deal how they can challenge and destruct the imperial government by establishing a new administrative system, Abo-gereb. Generally, the society has been practicing power decentralization and self-determination and this is a central and essential feature of the principle of democracy. Thus, it would not be wrong when I deserve the administrative system of Abo-gereb was indigenous democracy system. Moreover, the Abo-gereb has also a responsibility to manage and resolve inter-personal and between groups conflicts; it also control and manage environmental resources wisely and distributes fairly to the society in the province.

The members of abo-gereb are elected by the people considering certain requirements, like personal reliability, social acceptability and fairness in their administration. Thus, in Enderta's province of the abo-gereb system, power is distributed to local kebele, woreda and the province.

Even though, abo-gereb has a substantial role in democratizing the administrative system of the province, Tigray and Ethiopia in general, I also found it with some problems. Some of the problems of abo-gereb goes to the election system (i.e. abo-gereb is elected for the unlimited period of time) and this is my objection towards it. Moreover, they are not paid for their activities in administration and social negotiation and not universal (which is open to all).

The traditional democratic administrative system of Abogereb provokes self-representation and self-regulation system. This classic democracy has given a relative peace and stability to the society and a little bit political sovereignty. It also assures actualizing private property to the society in Enderta province and surrounding areas.

According to the classical administrative system of Abogerebe every one is equal, no master and slave class among the society. But, the abo-gereb administrative system left out women from taking part in, affiliating and involving in the political and social activities.

\subsection{Recommendation}

Currently, Ethiopia is identified with social, ethnic and political disputes in most parts of the country. Eccentric actions like killing of innocent peoples, destruction of private and governmental material wealthy have been dedicated throughout the country, except Tigray and Afar.

1. To resolve such ethnic based killings and harms, I recommend the local and central government to acknowledge and prudentially apply the Irki Enderta one and best dispute resolution of the Enderta province in Tigray and other indigenous dispute resolution.

2. Moreover, the local and central governments should improve the limitations of the traditional administrative 
system of Abo-gereb that I pointed out on the above topics. Some of the limitations are unlimited time authority of the abo-gerb, (i.e. they are elected for unlimited period of time) and this open a door for corruption and bias. This is aimed to follow and examine contemporary and update quality of the council elders I would say there must be periodic election of council elders (members of Abo-gereb) the members democratize the traditional dispute resolution system, Irki Enderta.

3. On the other hand my recommendation goes to the national regional government of Tigray to take experience from the abo-gereb principle of selfadministration, to rule the people by their representatives. It is known that administrative leaders of kebeles, weredas and zones in Tigray are elected by the will of the highest officials of the region, not by their representatives. This is an essential feature of federalism.

4. I also recommend the government of Tigray institutionalize, financially support and strengthen the indigenous conflict management and resolution apparatus of Abo-gerb in order to normalize, stabilize the social approach of the society and to make smooth relationship with neighbor regions (Amhara and Afar).

5. In addition to that, I recommend the regional government of Tigray take experience from Abo-gereb how to use resources fairly and equally. Meanwhile there is unfair distribution of resources in Tigray for a long time. Thus, I advised the regional government take experience from Abo-gereb to solve the problem and promote fair distribution of resources this may help for the development of democracy in Tigray.

6. Inviting and participating women in peace reestablishing events.

\section{References}

[1] https://en.wikipedia.org/wiki/Enderta_Province\#cite_note-2.

[2] Salt, H. (1814). A Voyage to Abyssinia. London.

[3] Young, J. (1997). Peasant revolution in Ethiopia. New York: Cambridge University Press.
[4] Sarah Vaughan (2003) Ethnicity and Power in Ethiopia, PhD Thesis, University of Edinburgh.

[5] https://www.researchgate.net/publication/280856789_A_shift from peasant to intellectual-

led_political_opposition_in_Tigray_during_the_imperial_regi me_up_to_1974.

[6] http://www.ityopis.org/Issues-1_files/ITYOPIS-I-Berhe.pdf

[7] Coser, L. A. (1968). "Conflict, Social Aspect” In international Encyclopedia of the Social Science. V. 3. Macmilian: Macmilian Company and Free press.

[8] Kinfe S (2014). Dispute Resolution Mechanisms among the Afar People of Ethiopia and Their Contribution to the Development Process. J. Transdisciplinary Res. Southern Afr. 10 (3): 152-64.

[9] Gowok, S. M. (2008). Alternative dispute resolution in Ethiopia - a legal framework. African Research Review, 2 (2), 265-285. Endalew, L. (2014). Ethiopian customary dispute resolution mechanisms: forms of restorative justice? African Journal of Conflict Resolution, 14 (1), 125-154.

[10] Zeleke, Meron 2010. Ye Shakoch Chilot (the court of the sheiks): A traditional institution of conflict resolution in Oromiya zone of Amhara regional state, Ethiopia. African Journal on Conflict Resolution, 10 (1), pp. 63-84.

[11] Kebede, Yidnekachew (Legal Researcher and Customary Law Research Team Leader in JLSRI [Justice and Legal System Research (Ethiopia)]) 2012. Interview with the author on 13 September 2012. Addis Ababa, Ethiopia. (Field notes in possession of the author.).

[12] Harrison, R. (2003). Hobbes, Locke, and Confusion's Masterpiece: An Examination of Seventeenth-Century. New York: Cambridge University Press.

[13] Marcus, H. G. (1994). A History of Ethiopia. London, England: University of California Press, Ltd.

[14] Hansen, M. H. (2005). The Tradition of Ancient Greek Democracy and its Imporatnce for modern Democracy. Copenhagen: The Royal Danish Academy of Sciences and Letters.

[15] Assefa, Getachew and Alula Pankhurst 2008. Facing the challenges of customary dispute resolution: Conclusions and recommendations. In: Pankhurst and Assefa eds.

[16] Stout, J. (2004). Democracy and Tradition. Princeton, New Jersey: Princeton University Press, 41 William Street. 